\title{
China's E-Economy: An overview of Opportunities and Threats
}

\author{
Qiao Yao (Corresponding author) \\ Limkokwing University of Creative Technology, Cyberjaya, Malaysia \\ E-mail: 13612808@qq.com
}

$\begin{array}{ll}\text { Received: February 8, } 2019 & \text { Accepted: February 26, } 2019 \quad \text { Published: March 20, } 2019 \\ \text { doi:10.5296/jad.v5i2.14526 } & \text { URL: https://doi.org/10.5296/jad.v5i2.14526 }\end{array}$

\begin{abstract}
China is the world biggest country in terms of population. It has the highest number of internet and mobile users. The world most substantial labor forces reside in China. A large proportion of the world is dependent on its exports. Chinas economy grew, in the last decade because of its exports, it got attention all over the world. Economy experts consider China as an economic threat to the USA. However, more studies are mainly focused on China populations, Exports, and labor focus because of the high quantity. The dynamics of the economy has changed in the last decade because of internet penetration across the globe. The Chinas role in digital aspects is least studied. Therefore this paper has focused on providing an overview of E-economy of China. Through literature and world-leading financial and consultancy firms reports it has been observed that just like other aspects of the economy, the e-economy of China is also growing. Today in 2019 where more than $50 \%$ of the world has access to the internet, It is considered that the Silicon Valley of USA is deriving the digital age because all big tech companies are located in the USA. USA main exports are Internet-related or Tech products. It is a fact that the USA E-economy contributes more to GDP compared to China. However, China has a potentially bright future in this area and can be the leading country in technology. Exploring the future possibilities, the opportunities which China has to grow in the digital age, the researchers found already there are areas in digital aspects where China has to outnumber the USA. For instance, the Fintech China got more Capital venture investments in 2016 compared to the USA. China is the world second country after the USA in attracting venture capital investment for Virtual Reality, Autonomous Driving, Wearables technologies, Education Technology, Robotics and drones, and 3D Printing. China is in the third position in terms of attracting investment for big data and artificial intelligence. The study concludes that China needs to focus more on big data and AI to continue its growth. The growing digitalization can improve agriculture and industrial activities as the economy is maturing. The paper is useful for digital experts to view the understand the e-economy in depth, future researchers can narrow down the topic to
\end{abstract}


observe the impact of E-economy on agriculture and industrial sector.

Keywords: e-economy, China, economic growth, economic opportunities, economic threats

\section{Introduction}

Digitization has impacted all walks of life (Farooq et al. 2018). The impact is not limited to companies performance (Buzdar et al., 2016) or individuals attitude in society (Khalil-ur-rehman \& Farooq, 2018; Qadir \& Farooq, 2018), It has also influenced the national level GDP (Bieńkowska \& Sikorski, 2017; Capineri \& Leinbach, 2004; Tan, 2001). At the national level, the impact of digitalization is called E-economy or digital economy. There are several definitions of Digital Economy based on its scope; however ever most of the researchers agree on two meanings. The first definition is based on technology. With the assumption that since the birth of computers in the $60 \mathrm{~s}$ or market of microelectronics in the $40 \mathrm{~s}$, the introduction of internet in 90s, Introduction of social sites like Facebook, Twitter in early 2000 and in latest the Artificial intelligence, the Blockchain, and robotics, the economy has added new sectors. In regard, for instance, e-commerce is an entirely new domain. Companies like Amazon, E-bey, and Alibaba are today counted as world biggest companies. Similarly, in FinTech, transportation, and communication, the new developments are changing the way we work. The first definition is a narrowed definition covering the digital technology part. The narrow definition only includes Information, Communication, and Telecommunication (ICT). The narrow definition was provided by OECD. OECD is the mission of the Organization for Economic Co-operation and Development (OECD) is to promote policies that will improve the economic and social well-being of people around the world (Definition). While This definition was given by G20. The G20 defines the digital economy as:

"a broad range of economic activities that includes using digitized information and knowledge as the key factor of production, and modern information networks as the important activity space."

The China Academy of Information and Communication Technology (CAICT) applies the broad definition of the Digital Economy. As per the broad interpretation the national accounts and measures the size of the digital economy to be about 30 percent of GDP doubling since 2018.

\section{Chinas Economy: Detailed Overview}

As per Woldometer (2019) statistics, China is the world most populous country. Its population is 1.4 Billion. Besides India and China rest, all countries have below than 1 billion population. Table 1 shows the population of the top 10 countries worldwide. 


\section{Macrothink}

Table 1. The population of the top 10 countries worldwide

\begin{tabular}{lll}
\hline Sr. & Country & Population \\
\hline 1 & China & $1,418,083,720$ \\
2 & India & $1,362,932,903$ \\
3 & U.S.A. & $328,174,624$ \\
4 & Indonesia & $268,453,068$ \\
5 & Brazil & $211,790,696$ \\
6 & Pakistan & $203,097,774$ \\
7 & Nigeria & $198,942,641$ \\
8 & Bangladesh & $167,394,993$ \\
9 & Russia & $143,922,793$ \\
10 & Mexico & $131,707,678$ \\
\hline
\end{tabular}

Source: Worldometer.com.

Because the population of China is a very big economy, it is the world number one economy in the world in many aspects. For example, the GDP of China in 2017 was 32.21 trillion. In the last decade, it was one of the fastest growing GDP. China has the biggest labor force. It has around 806.7 trillion in labor force. Most of the electronic products are produced in China; for instance, world-leading companies like Apple has manufacturing plants in China. China is also the biggest country in terms of exports. Its exports are increasing from the many previous years. In 2017, China's exports increased from 1.99 trillion (2016) to 2.216 trillion in (2017). Chinese people and China as a country are also popular because of its saving nature. The Foreign exchange reserves of China in 2017 were estimated as 3.236trillion US dollar compared to 3.098 trillion in 2016. China is not world number one in many another aspect of the economy for example in GDP growth rate it is now world $21^{\text {st }}$ country. In terms of Per capita income, the numbers of the Chinese economy are not good and its ranked as world $105^{\text {th }}$ country. China's GDP is composed of $7.9 \%$ of agriculture, $40.5 \%$ of the industry and services occupy $51 \%$ of the GDP. China is also controlling the unemployment rate. The unemployment rate in China has reduced from 4\% in 2017 to 3.9\% in 2016. The below table shows the overall economy of China in detail. 
Table 2. Overall economy of China in detail

\begin{tabular}{lllll}
\hline Sr. & Economic Aspect & $\mathbf{2 0 1 7}$ & $\mathbf{2 0 1 6}$ & Rating \\
\hline 1 & GDP (Purchasing power parity) & $\$ 23.21$ trillion & $\$ 21.72$ trillion & 1 \\
\hline 2 & Labor force & 806.7 million & 1 \\
\hline 3 & The stock of narrow money & $\$ 8.351$ trillion & $\$ 7.001$ trillion & 1 \\
\hline 4 & The stock of broad money & $\$ 8.351$ trillion & $\$ 7.001$ trillion & 1 \\
\hline 5 & Stock of domestic credit & $\$ 27.34$ trillion & $\$ 23.02$ trillion & 1 \\
\hline 6 & Exports & $\$ 2.216$ trillion & $\$ 1.99$ trillion & 1 \\
\hline 7 & Foreign exchange \& gold Reserve & $\$ 3.236$ trillion & $\$ 3.098$ trillion & 1 \\
\hline 8 & GDP Growth Rate & $6.90 \%$ & $6.7 \%$ & 21 \\
\hline 9 & GDP per capita (PPP) & 16700 & 15700 & 105 \\
\hline 10 & Gross national saving & $45.8 \%$ of GDP & $45.9 \%$ of GDP & 6 \\
\hline
\end{tabular}

11 GDP - composition, by end use

12 GDP - composition

13 Agriculture - products

14 Industries
Household consumption: $39.1 \%$, government consumption: $14.5 \%$, investment in fixed capital: $42.7 \%$ investment in inventories: $1.7 \%$, exports of goods and services: $20.4 \%$, imports: $-18.4 \%$

agriculture: $7.9 \%$, industry: $40.5 \%$, services: $51.6 \%$

The world leader in gross value of agricultural output; rice, wheat, potatoes, corn, tobacco, peanuts, tea, apples, cotton

The world leader in gross value of industrial output; mining and ore processing, iron, steel, aluminum, and other metals, coal; machine building; armaments; textiles and apparel; petroleum; cement; chemicals; fertilizer; consumer products

$6.1 \%$

40
16 Labor force - by occupation

Agriculture: $27.7 \%$, Industry: $28.8 \%$, Services: $43.5 \%$ 
17 Unemployment rate

$3.9 \%$

$4 \%$

48

18 Population below poverty line

$3.30 \%$

19 Family income distribution- Gini index

31

20 Budget

Revenues: 2.553

trillion, -

Expenditures: 3.008 trillion

\begin{tabular}{|c|c|c|c|c|}
\hline 21 & Taxes and other revenues & $21.3 \%$ (of GDP) & - & 41 \\
\hline 22 & Budget surplus $(+)$ or deficit $(-)$ & $-3.8 \%$ (of GDP) & - & 152 \\
\hline 23 & Public debt: & $47 \%$ of GDP & $44.2 \%$ of GDP & 111 \\
\hline 24 & Inflation rate (consumer prices): & $1.6 \%$ & $2 \%$ & 88 \\
\hline 25 & Central bank discount rate & $2.25 \%$ (5 December 2017 est.) & $2.25 \%$ & - \\
\hline 26 & $\begin{array}{l}\text { The market value of publicly } \\
\text { traded shares }\end{array}$ & - & $\$ 7.335$ trillion & 2 \\
\hline 27 & Current account balance & $\$ 164.9$ billion & $\$ 202.2$ billion & 3 \\
\hline 28 & Exports - partners & \multicolumn{3}{|c|}{ US 19\%, Hong Kong $12.4 \%$, Japan $6 \%$, South Korea 4.5\% } \\
\hline 29 & Exports - commodities & \multicolumn{3}{|c|}{$\begin{array}{l}\text { Electrical and other machinery, including computers and } \\
\text { telecommunications equipment, apparel, furniture, textile }\end{array}$} \\
\hline 30 & Imports & $\$ 1.74$ trillion & $\$ 1.501$ trillion & 2 \\
\hline
\end{tabular}

Source: CIA World Factbook.

\section{Chinas E-Economy: Detailed Overview}

As per the Narrow definition, only 6\% of China GDP comes from the E-economy (4) compared to the rest of the Asian countries in the region, this count is very less. For instance, South Korea and Japan have 8-10\% of GDP from E-economy because their Information Technology industry is more developed and well established. Japan and Korea electronic products are counted as reliable and quality products While the broader definition which also used to China own economy team, says that the E-economy is almost $30 \%$ of overall GDP. Also shown in the below chart the count of e-economy is per broader definition is also low 
compared to the United States, Japan and Brazil, India and South Africa.

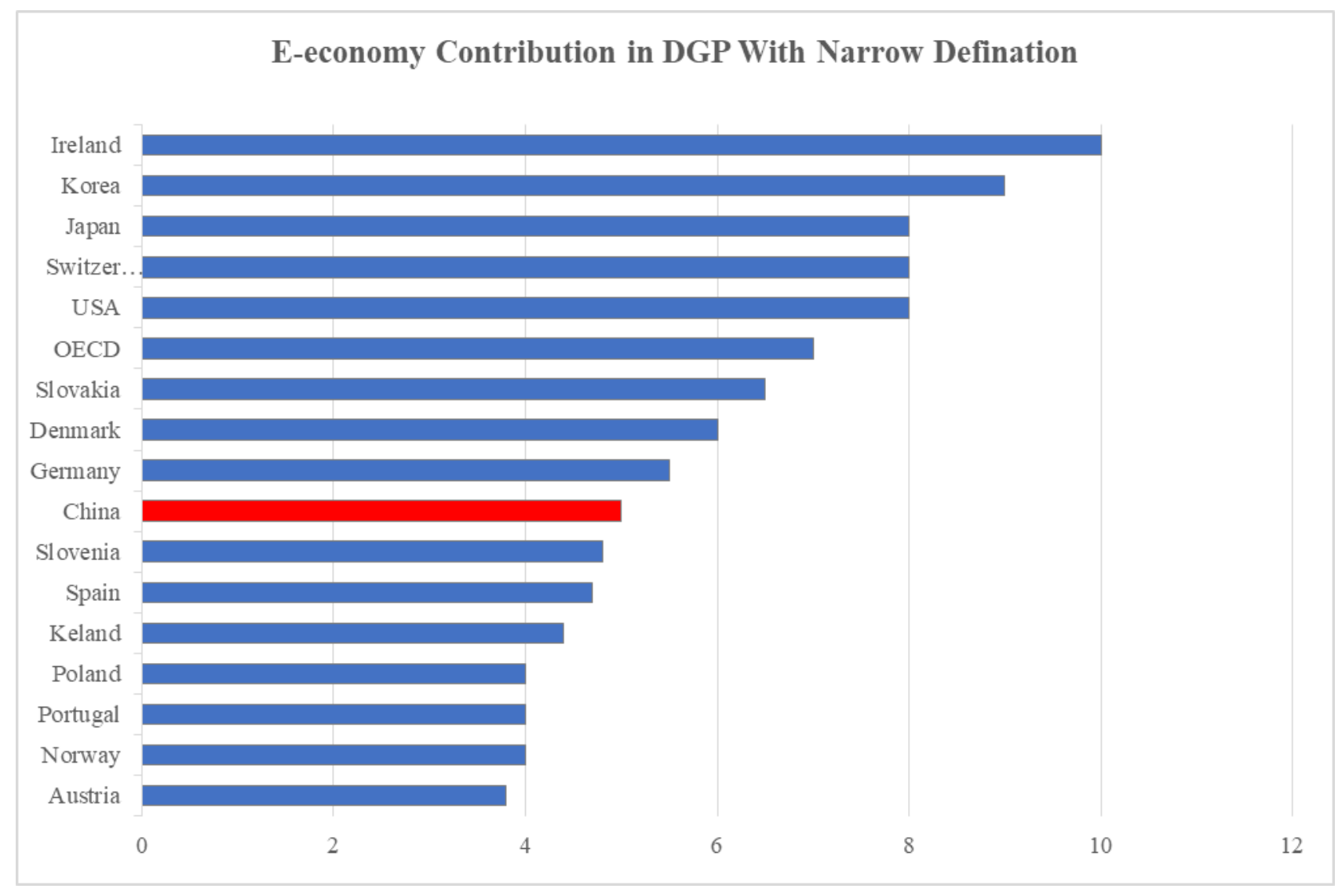

Source: (IMF, 2018)

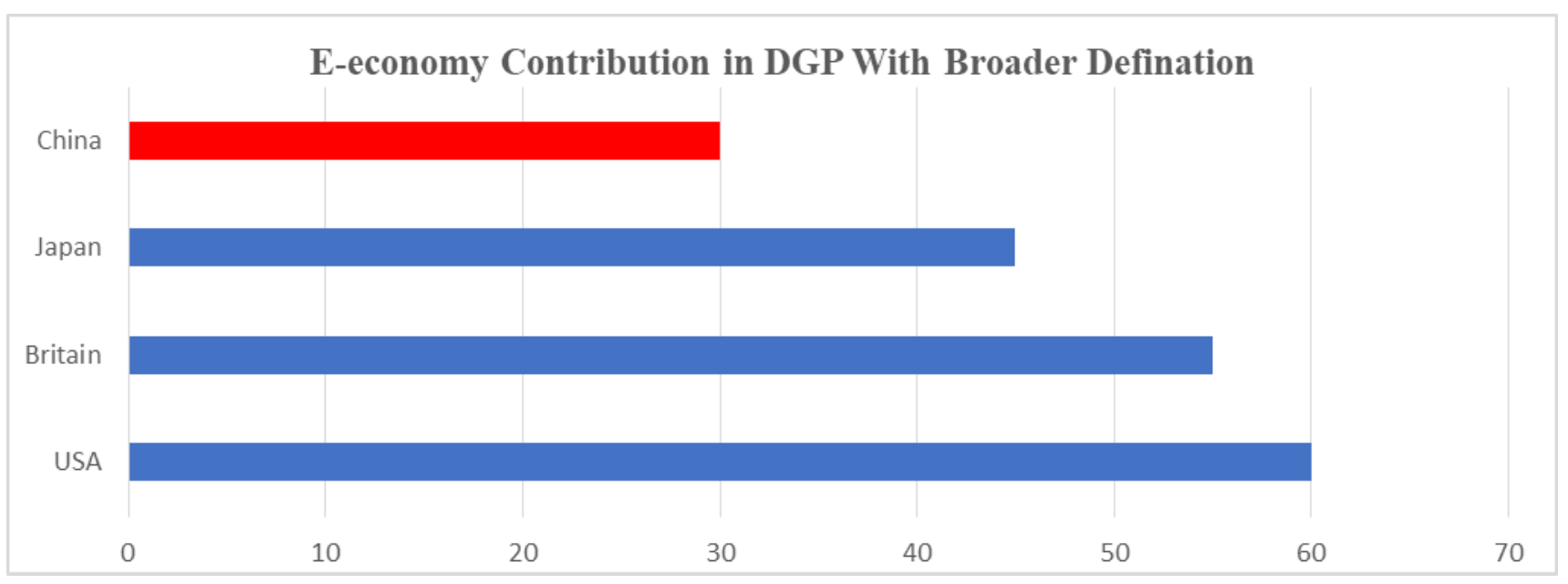

Source: (IMF, 2018)

Figure 1. The count of e-economy is per broader definition is also low compared to the United States, Japan and Brazil, India and South Africa 


\section{Macrothink Institute ${ }^{T M}$}

Despite all these rankings and states, China is leading many digital channels. As per the report published by the IMF, China is leading for example:

In the e-commerce world, $40 \%$ of online transactions are being done on China's portals. In China, there are multiple e-commerce companies which are helping to connect China's business to the rest of the world in the domain of B2B and B2C. Alibaba is leading this market. Alibaba has more than $50 \%$ of market share in e-commerce. The second e-commerce companies are JD.com which has $16.3 \%$ of market share while the third company is Pinduoduo which has $5.2 \%$ of the market share. Alibaba in the world is known as a well-known e-commerce firm (Schmitz, Stummer, \& Gerke, 2019)

\section{Alibaba continues to lead retail e-commerce sales in China} Top 10 e-commerce retailers in China as of June 2018, by sales share*

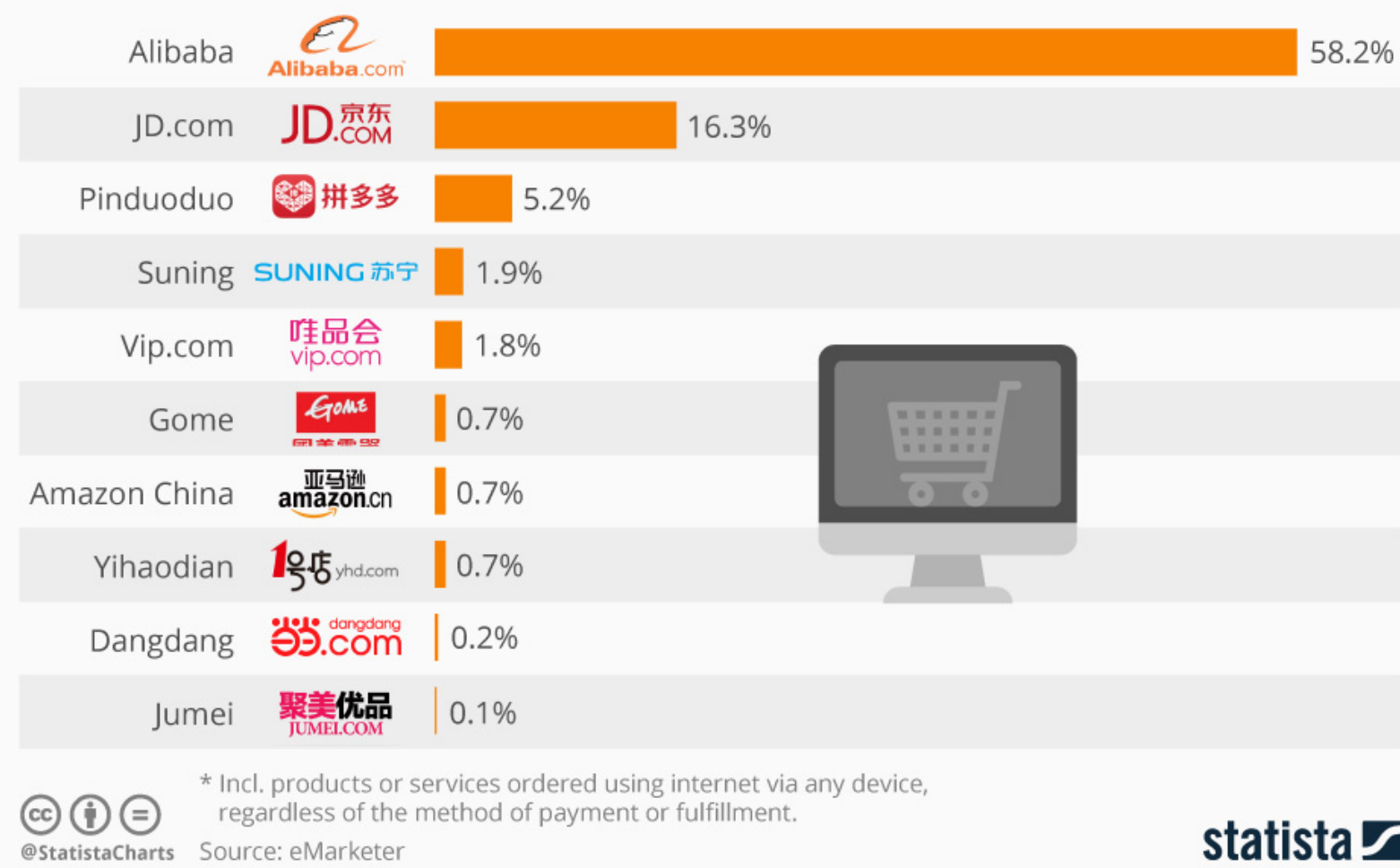

Figure 2. Alibaba continues to lead retail e-commerce sales in China

On the fintech industry, Chinese companies have gained more than 70 percent of the total global market share valuations. The value of China's consumption-related mobile payments by individuals totaled US $\$ 790$ billion in 2016, 11 times that of the U.S. Related to the growth of this sizable market, the processing capacity of one of China's largest mobile payments providers Alibaba is roughly 3 times faster than of U.S. counterparts. As Mckinsey report, the capacity of Alibaba to process per the second transaction is 120,000 transaction vs. 28,000 US leading e-commerce sites. In the ecosystem of payment, the Alipay is changing the way transactions are done. Below figure shows the complete ecosystem of Alipay. The rapid 


\section{Macrothink}

increase in the adaption of Ali Pay and other digital apps has created a service industry which is growing exponentially. Digitization is helping all the categorize in services (Farooq, Muhammad, Raju, Kalimuthu, \& Qadir, 2019); it is helping people in managing finances through the digital way. The digital payment system is improving the payment system. Even investment in the digital apps is providing the customers the one-stop shop experience. The supper apps like We chat are giving the opportunity to manage their payment and communication at one place. Besides this, some app also helps the consumers to manage the health, education and transportation expenses in one mobile app. In China, pollution is a very big problem, and every person is concerned about the increasing population, Digitalization is also helping Chinese consumers in this area. For instance, Ant Financial have development one Ant forest, a mobile app that integrates the Carbon emission with the by tracking the individual consumptions based on their activities. The Ant forest app had around 288 Million users by the end of 2017. With a cumulative strategy to avoid the carbine emission because of this app, 2.05 million tons of carbon emission was avoided. Because of this app, more than 13 million trees were planted to make the environment better. The digitalization is not only helping the online businesses, but it is also helping in improving the ecosystem and creation of the green environment.

Digital payment systems like Alipay app are working on multiple categories to incorporate the payment systems and help people to do digital transactions. In every section, Alipay offers different services. It covers multiple categories with multiple features. For example, finances are the top category, it covers, the transportation, utilities, and social services, shopping, social, communication, education, dining, charitable donations, entertainment, health, and media,

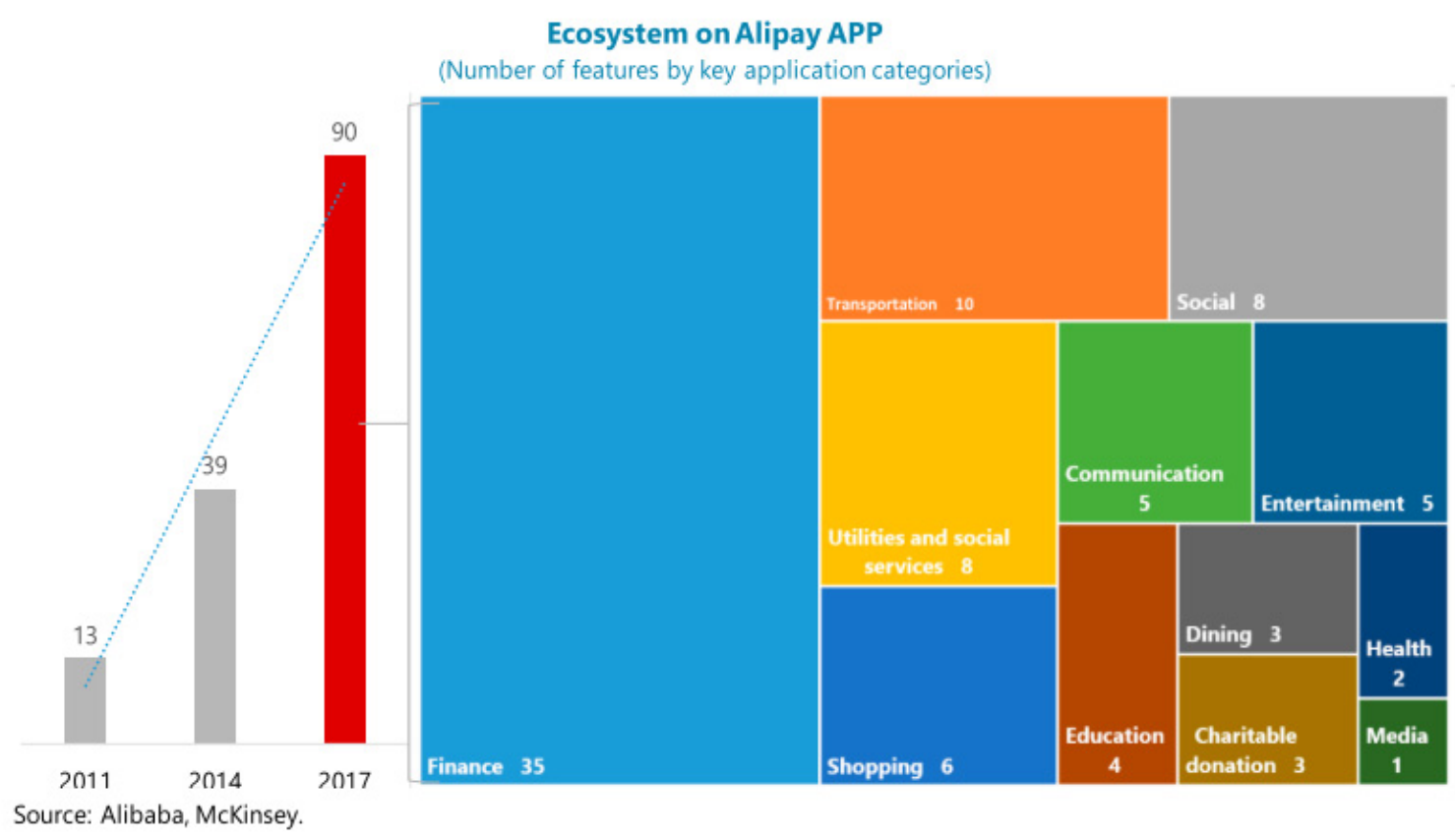

Figure 3. Ecosystem on Alipay APP 


\section{Macrothink}

Krämer and Jalajel (2019) The biggest advantage which the digitization brought in China is the poverty reduction. Before digitization, the middle man was extremely important, and there was no way that the small manufacturer, small farmers, and artists in for flung areas of China could interact with the final decision makers. The middle man was talking goods at low price form the businesses and selling to companies at a high price. Transportation and access were also difficult. The reason why Alibaba became so popular was that of tapping this unexplored area. However, the E-economy brought real benefit in the form of reduction of poverty. It connects remote regions to the consumers living in urban area. For instance, Ali Baba has promoted more than 1300 villages in Taobao in China.

As per the world bank report in 2017, the digitalization has also increased financial inclusion. With increased internet penetration, the people in remote regions started using the internet and then the telecom companies started providing financial services which brought many people in financial inclusion net. Some researchers also criticize that increased financial inclusion has widened inequality. Only those people who were educated got the advantage of the internet and sold their products directly to the urban area. This scenario creates the need to explore the benefits of E-economy vs. threats of E-economy. Therefore in the next section of the research paper, we will discuss the benefits of E-economy vs. Threats of E-economy which it brings to China.

\section{Opportunities and Threats for E-Economy of China}

(Schulz, Wieker, \& Arnegger, 2019) wrote one report on China's Digital Economy. The author is of the opinion the E-economy will bring a lot of opportunities for China. The success of China is a case study for any investors. In 2005, the e-commerce transaction value was $<1 \%$, the transaction value expended in 2016 and it became $42.4 \%$. The united states transaction value reduced from 35 to $24.1 \%$ billion, While the rest of world contribution reduced from $64.6 \%$ to $33.5 \%$ giving up all the share for China. The Mobile Payment gap between USA and China become 11times. China mobile payment increase 11times more compared to USA payments. Similar global unicorns of China have also increased in 2016 compared to the rest of the world. In coming years the experts believe China will continue to grow in payments and other e-commerce areas. Alibaba is extending its branches outside China, for example, it has brought the Daraz.pk in Pakistan, and it's going to open multiple investments in Malaysia. 
China's digital economy is a story of commercial success and excitement among investors

China United States $\quad$ Rest of the world

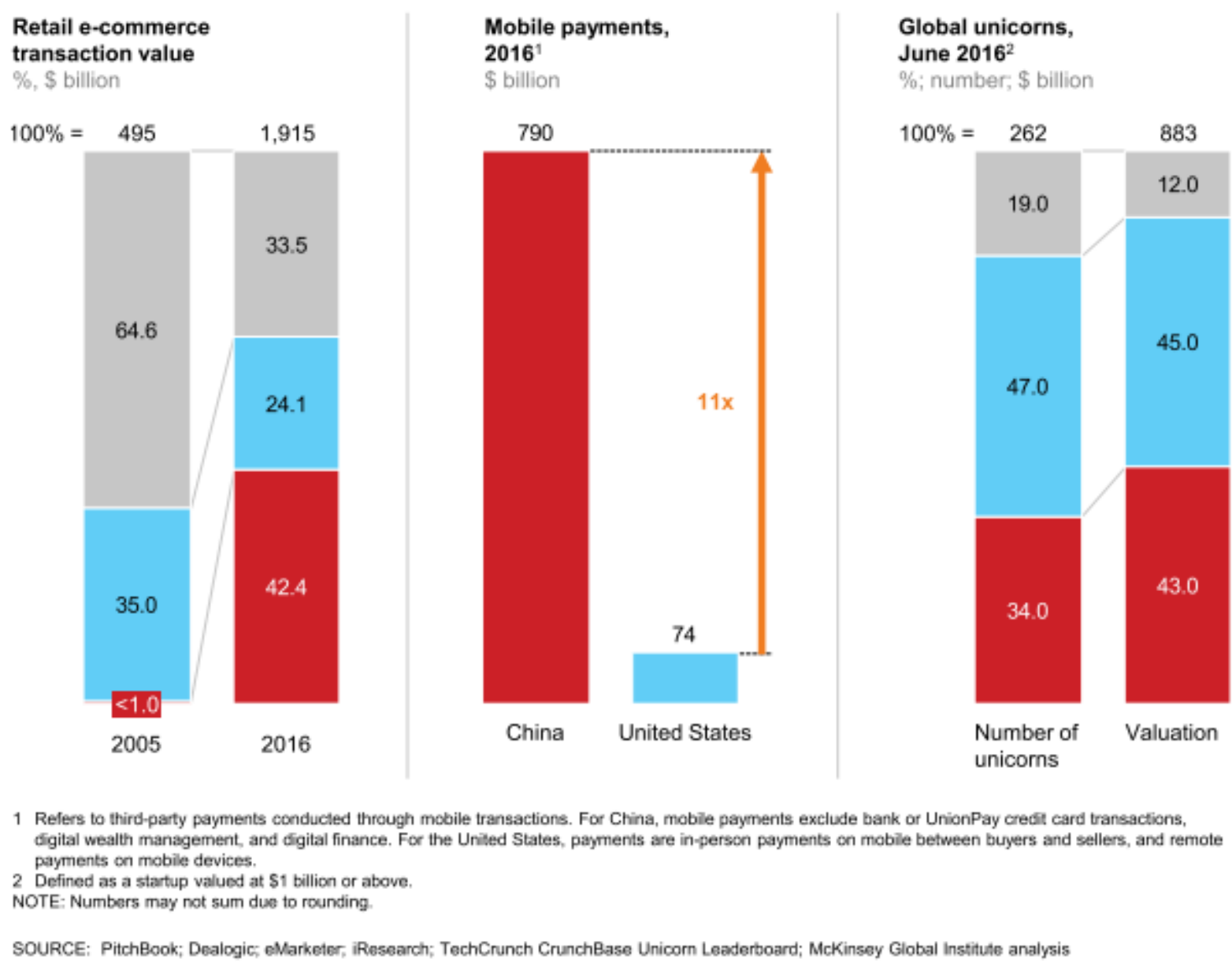

Figure 4. China's digital economy is a story of commercial success and excitement among investors

In 2016, in venture capital investments, China got more investment compared to united states, united kingdom, Germany and Japan. In the fintech industry, total investment in China was $\$ 7,158$ million vs. $\$ 5,437$ million in the USA. The Japan key competitor of China in the last decade could only secure $\$ 493$ million in fintech investments. Another area where the China E-economy is growing is virtual reality; in virtual reality, China stood second. Compared to the USA $\$ 1,437$ million in China $\$ 1,312$ million were invested. Japan, the close competitor of China, could only gain $\$ 166$ million.

In the category of Autonomous driving where Japan technology and investments were very popular before 2000 and e-economy, China has left Japan behind in this area. Regarding the investments the autonomous driving, the United States was top country in 2016. It has gained \$562 million while the second country which gained investments was China, it gains $\$ 357$ million investment. Japan could only get an investment in 268 million. The other two 
countries which were among 5 countries which get investment in this area were Australia and United Kingdome.

Table 3. Venture capital investments in key technologies (\$ Million)

\begin{tabular}{lllll}
\hline Key Technology & United States & China & United Kingdome & Japan \\
\hline Fintech & 5,437 & 7,158 & 1,793 & 493 \\
Virtual Reality & 1,437 & 1,312 & 73 & 166 \\
Autonomous Driving & 582 & 357 & 142 & 268 \\
Wearables & 1,724 & 992 & 95 & 90 \\
Education Technology & 1,282 & 681 & 163 & 217 \\
Robotics and drones & 728 & 227 & 113 & 129 \\
3D Printing & 602 & 221 & 171 & 181 \\
Big Data & 6,055 & 942 & 1,673 & 473 \\
AI \& Machine Learning & 3,782 & 900 & 1,222 & \\
\hline
\end{tabular}

Source: Mckinsey (2017).

In the category of wearables, in terms of investment done in 2016 and future opportunities, China stood the second country. The United States of America stood first company with an investment of $\$ 1,724$ million followed by China with an investment of 992 million. The close competitor of China, Japan could not even secure its position in top $5^{\text {th }}$ countries.

In the category of Education technology, in terms of investment done in 2016 and future opportunities, China stood the second country. The United States of America stood first company with an investment of \$1,282 million followed by China with an investment of $\$ 62$ million. The close competitor of China, Japan only \$217 million investment in 2016.

In the category of Robotics and drones, in terms of investment done in 2016 and future opportunities, China stood the second country. The United States of America stood first company with an investment of $\$ 726$ million followed by China with an investment of $\$ 227$ million. The close competitor of China, Japan only $\$ 129$ million investment in 2016. The other countries which secured investments in the category were Singapore and Canada. 
In the category of 3D printing, in terms of investment done in 2016 and future opportunities, China stood the second country. The United States of America stood first company with an investment of $\$ 602$ million followed by China with an investment of $\$ 181$ million. The close competitor of China, Japan only $\$ 181$ million investment in 2016. The other countries which secured investments in the category were Singapore and Canada.

It's often said the data in the future, and data is new oil in the future economy. When it comes to data, the big data is mostly referred to. Big data is connected with artificial technology and future developments. In the category of Big data in terms of investment done in 2016 and future opportunities, China stood the third country. The United States of America stood first company with an investment of $\$ 726$ million followed by United Kingdome with the investment of $\$ 1673$ million. China stood third in this category with total investments of $\$ 990$ million. The close competitor of China, Japan could not secure the position in the top 5 countries which invested In big data. Surprisingly Singapore in Asia is a competitor of China in the domain.

In the category of Artificial intelligence and machine learning, in terms of investment done in 2016 and future opportunities, China stood the third country. The United States of America stood first company with an investment of \$1222 million followed by United Kingdome with an investment of $\$ 1673$ million. China stood third in this category with total investments of $\$ 900$ million. The close competitor of China, Japan could only secure worth $\$ 473$ million.

Besides investments, because of its huge size and population, China has more opportunities. China has 1.7 times more internet users than in Europe and India. It has 2.5 times more internet users compared to the united states.

Table 4. China vs. Rest of World (In Millions)

\begin{tabular}{lllll}
\hline & China & India & $\mathrm{Eu}$ & united States \\
\hline Total internet users & 731 & 432 & 434 & 287 \\
Mobile Internet users & 695 & 371 & 343 & 262 \\
Digital Natives & 282 & 160 & 135 & 75 \\
\hline
\end{tabular}

Source: Mckinsey (2017).

Mobile internet usage is also increasing in China. Compared to India and Europe it has 2.7 times more internet users. Again because of its size China has the highest number of digital natives in its population compared to the rest of the world. Compared to India, Europe, and united states it has 3.8 times more, digital natives. Despite all the growth and outnumbering Japan in almost all aspects of economy China is undisputedly the second largest economy in the world. It is a fact that in Big data and Artificial intelligence still united states and united Kingdome got more opportunities compared to China. Europe and USA are located in the 
same place. It can see from the graphs of investment it can be observed in Asia only China is growing. None of its neighbors could get the position among the top 5 countries. The main all companies, search engine, and big data related companies are working from the USA which is a threat to China.

\section{Conclusion}

It has been observed that Chinas economy grew exponentially in the last decade. In terms of GDP, Labor force, Stock of narrow money, Stock of broad money, Stock of domestic credit, Exports and Foreign exchange \& gold Reserve it is world number one country. China has a strong economy with enormous opportunities. Main GDP industries are services and manufacturing; however, agriculture also contributes reasonably in the GDP. Because of manufacturing and exports, China is helping the world. The worrying part observed in the paper, despite this much GDP and the labor forces the GDP per capita is very low. A country where in terms of GDP country is on top and the GDP per capita is low is a clear representation of inequity.

After the overall economy review, we discussed the e-economy in China. It was observed that China has a tech-savvy population. The number of internet users is highest in the world, compared to USA China has 2.5 times more mobile connections. In terms of Digital natives as a proportion of online users that China has 3.8 times more native digital users compared to China, India, Europe, and united states.

McKenny report of 2016 shows that in all e-economy parameters, e-commerce is growing in China. In 2016, the retail e-commerce companies of China did a $42.4 \%$ \$billion transaction compared less than $1 \%$ transactions in 2005. Mobile payments become 11 times higher in China compared to United States.

In Asia, China has become an undisputed leader in capital investment in key technologies. Compared to its competitors in Asia which are Japan, Korea, and Singapore China attracted more investments. In fintech, virtual reality, autonomous driving, wearables, education technology, robotics and drones, and 3D printing China is world second country after the USA to have investments in the digital era. In some areas, China stood third, for instance in Big data and Artificial intelligence and machine learning the United Kingdome got more investments.

All these investments created a lot of opportunities for China, China as a country 20 years ago was not counted among top countries today is counted as the biggest economy. However as it grew in manufacturing and agriculture, China could not grow in technology. All indicators of technology, China stood second. Its competitors in Asia, for instance, Japan is still a prominent force in the world competing with China. However, the future of China in the digital age is bright; it can be one of the leading economies in the coming years in terms of economy and leading economic drive across the world (Eberhard \& Heuermann, 2019a, 2019b; Heilen, 2019; Heuermann, 2019; Krämer, 2019; Lundborg, 2019; Steingröver, Cardozo Larrea, \& Zhelev, 2019). 


\section{References}

Bieńkowska, J., \& Sikorski, C. (2017). Changing the philosophy of organization management in the times of e-economy. Management, 21(2), 1-13. https://doi.org/10.1515/manment-2017-0001

Buzdar, M. F., Janjua, S. Y. S. Y., Khurshid, M. A. M. A., Farooq, M., Janjua, S. Y. S. Y., \& Khurshid, M. A. M. A. (2016). Customer-based brand equity and firms' performance in the telecom industry. International Journal of Services and Operations Management, 25(3), 334. https://doi.org/10.1504/IJSOM.2016.079516

Capineri, C., \& Leinbach, T. R. (2004). Globalization, E-economy, and Transport, 34(4), 385-389.

Eberhard, U., \& Heuermann, A. (2019a). Open Access via Mobile Wholesale Network: A New Approach to Broadband Deployment: The Case of Mexico. In Future Telco (pp. 263-271). https://doi.org/10.1007/978-3-319-77724-5_23

Eberhard, U., \& Heuermann, A. (2019b). Open Access via Mobile Wholesale Network: A New Approach to Broadband Deployment: The Case of Mexico. In Future Telco (Vol. 4, pp. 263-271). https://doi.org/10.1007/978-3-319-77724-5_23

Farooq, M., Muhammad, S., Raju, V., Kalimuthu, K. R., \& Qadir, A. (2019). Measuring and Comparing the Desired and Actual Service Quality of Pakistan International Airline. The Journal of Social Sciences Research, (52), 484-490. https://doi.org/10.32861/jssr.52.484.490

Heilen, T. (2019). Becoming Faster and More Direct: Telco Carrier Product Management Turns Towards Customers, Partners and Colleagues. In Future Telco (Vol. 8, pp. 187-194). Pro Rhetoric, LLC. https://doi.org/10.1007/978-3-319-77724-5_16

Heuermann, A. (2019). OTTs Versus Telcos: Network Neutrality and Operator Strategies. In Future Telco (Vol. 36, pp. 251-261). Oxford University Press/USA. https://doi.org/10.1007/978-3-319-77724-5_22

Khalil-ur-rehman, F., \& Farooq, M. (2018). Deployment of Mobile Learning in Advanced Education Foundations, 18(6).

Krämer, C. (2019). Success with Partnering: Results of an International Study. In Future Telco (Vol. 67, pp. 197-210). China Today. https://doi.org/10.1007/978-3-319-77724-5_17

Krämer, C., \& Jalajel, R. (2019). OTT Partnering with Telcos: On the Rise. In IMF (pp. 211-218). https://doi.org/10.1007/978-3-319-77724-5_18

Lundborg, M. (2019). Regulation of Telecom Markets and OTTs in Europe is Uneven with Impact on Network Operators. In Future Telco (Vol. 164, pp. 233-240). https://doi.org/10.1007/978-3-319-77724-5_20

Muhammad, F. (2018). Impact of Digitalization on Holy Quran Readers; Experience and Expectations. IOSR Journal Of Humanities And Social Science (IOSR-JHSS), 23(7), 59-67. https://doi.org/10.9790/0837-2307035967 


\section{Macrothink}

Journal of Asian Development

ISSN 2377-9594 2019, Vol. 5, No. 2

Qadir, A., \& Farooq, M. (2018). Impact of Evaluation Apprehension on Knowledge Sharing Intention through Attitude and Perceived Behavioural Control. International Journal of Academic Research in Business and Social Sciences, 8(6), 795-811. https://doi.org/10.6007/IJARBSS/v8-i6/4274

Schmitz, M., Stummer, C., \& Gerke, M. (2019). Smart Automation as Enabler of Digitalization? A Review of RPA/AI Potential and Barriers to Its Realization. In Future Telco (pp. 349-358). https://doi.org/10.1007/978-3-319-77724-5_31

Schulz, W. H., Wieker, H., \& Arnegger, B. (2019). Cooperative, Connected and Automated Mobility. In Mckinsey Global Institute (pp. 219-229). https://doi.org/10.1007/978-3-319-77724-5_19

Steingröver, M., Cardozo Larrea, E. B., \& Zhelev, N. (2019). The Rise of OTT Players: What is the Appropriate Regulatory Response? In Future Telco (Vol. 45, pp. 241-249). https://doi.org/10.1007/978-3-319-77724-5_21

Tan, L. (2001). Informatisation for / an E-Economy in China.

\section{Copyright Disclaimer}

Copyright for this article is retained by the author(s), with first publication rights granted to the journal.

This is an open-access article distributed under the terms and conditions of the Creative Commons Attribution license (http://creativecommons.org/licenses/by/4.0/). 